CRYSTALS AND X-RAYS. KathleEN Lonsdale, D.Sc., F.R.S. London: G. Bell \& Sons, 1948, I90 pages. 2 Is.

THIs book is based on a series of lectures which the author gave at University College, London. It is intended to show physicists, chemists and others interested in X-ray crystallography the physical principles which underlie X-ray analysis. It also gives a general survey of its applications. The great contrasts between the standards of severity in different parts of the book rather reminded the reviewer of a typical alpine climb, a feature which is bound to attract the glaciological reader. Let us try to pursue this analogy.

Mrs. Lonsdale starts her climb into the X-ray country on the gentle slopes of the intelligent reader's everyday experience. An easy path leads him through much familiar scenery while sweet flowers in the form of simple parables distract his eyes from the steep cliffs that loom ahead. Whenever he puffs a little under the strain of intellectual effort Mrs. Lonsdale spurs him on with attractive pictures giving him a foretaste of the glorious views to be seen from the summit.

So pleasant is the going through the foothills of this land of $\mathrm{X}$-rays that the climber arrives at the end of the second chapter hardly realizing the distance already covered. But as he enters the third, the ground rapidly changes. Polyhedra of every shape obstruct his progress, his feet get entangled in networks of lattices, at times he has to wind his way up spiral paths, at others to ascend scree-like slopes called glide planes where his foot slips sideways for every step it advances. Crystal Geometry is the name of that passage.

After a short rest, the guide begins the famous traverse through reciprocal space, working her way along the slippery surface of the sphere of reflection. This is tough going for the non-crystallographer, but the lucid diagrams offer plenty of hand and footholds and the rock is always firm. Yet the real test is to come in Chapter V, which shows us how to find atomic and electronic distributions. Though the guide avoids the severest route via the complex exponentials, even her easier way through the real trigonometric functions requires a steady head and a firm grip. The Fourier projections especially seem dangerously exposed; yet Mrs. Lonsdale hardly allows us to take breath before plunging straight into vector space where giddiness is known to have overcome even fully trained physicists. Perhaps this is why her stay there is so short. Or is it because the summit is already in sight?

For with another few steps we arrive at the top of a mountain overlooking a seemingly endless plateau, and the magnificent panorama of the X-ray land unfolds itself before our eyes. We hardly know what to admire more: the varied beauty of the view or our guide's complete and detailed knowledge of it. Texture analysis and crystal dynamics, rocks and dyes, rings and resonance,
fibres and metals, are all explained with lucid brevity.

Though the intricacies of $\mathrm{X}$-ray analysis may be difficult for the non-physicist to follow, the book contains a wealth of interesting material for all who are interested in the atomic structure of things-including ice.

M. F. Perutz (Cambridge)

\title{
GLACIER FLUCTUATION IN THE ALPS
}

THE recession of the Swiss Glaciers proceeded with increased speed during 1947. In his annual report* Dr. P. L. Mercanton points qut that during the winter of $1946 / 47$ the precipitation averaged some three-quarters of normal, while during the six summer months the mean temperature and insolation exceeded their normal values by $3^{\circ} \mathrm{C}$. and 20 per cent respectively. The resulting ablation removed not only the whole of the winter accretion of snow but also a large quantity of the reserves of glacier ice. The only recorded exception was on the Jungfraufirn, where a small surplus of winter snow remained. On the Bristenstock the firn line rose to $2520 \mathrm{~m}$.,

- Die Alpen, Vol. 24, No. 11, 1948, p. 387-94. 
about $170 \mathrm{~m}$. higher than in 1946 and $270 \mathrm{~m}$. higher than in 1945 . Some exceptionally heavy recessions of glaciers are noted in the tables given; the Allalin Glacier snout receded $140 \mathrm{~m}$., the Tsanfleuron Glacier, in the basin of the Aar, $4 \mathrm{I}$ m., the glacier from Piz Sol in the Rhine basin $73 \mathrm{~m}$., and the Basodino Glacier in Ticino $116 \mathrm{~m}$. In 1946 13 per cent of the glaciers measured had advanced, 7 per cent were stationary and 80 per cent were in recession. $\dagger$ In 1947 none advanced, 2 per cent were stationary and 98 per cent had retreated.

\section{A B S T R A C T S}

Bowden, F. P. Friction. Science News. (Penguin Books, London), No. 4, 1947, p. 139-68.

Dr. Bowden discusses the principles of friction of metals and other substances in the light of recent knowledge and shows that through minute inequalities in the unlubricated surfaces of metals the real area of contact is very small and the local pressure considerable, thus impeding sliding.

The sliding properties of snow and ice are due to a lubricating layer of water. This is not caused by pressure melting but by local friction. Friction on snow and ice increases markedly as the temperature falls and is lowest for a slider possessing low heat conductivity, which prevents the heat generated by friction from escaping. Thus wood is a better possessing low heat conductivity, which prevents the heat generated or edges of German silver or constantan are better on cold snow than those made of brass or steel.

Cwilong, B. M. Sublimation in outdoor air and seeded sublimation. Nature, Vol. 163, No. 4149, I 949 , p. 727.

In continuation of the author's expansion chamber tests in England of the threshold temperature for the formation of ice crystals it was found that in strong sea winds in New Zealand (force 5 and more) the value remains constant at $-4 \mathrm{I} \cdot 2^{\circ} \mathrm{C}$. as before. In other weather the value varies between $-4 \mathrm{I} \cdot 2^{\circ} \mathrm{C}$. and $-32 \cdot 2^{\circ} \mathrm{C}$., the latter figure being the same as that for the ground layer of air in England.

Expansion chamber and frost point hygrometer tests were made of the seeding properties of silver iodide. The threshold sublimation temperature in both cases was $-2.9^{\circ} \mathrm{C}$. with small variants. Sublimation on surfaces seeded with silver iodide commences at temperatures somewhat lower than the frost point of the air under investigation, but the silver iodide commences at temperatures somewhat lower than the frost point of the air under investigation, but the owing to the reduction of the temperature range at which the observer can confuse ice and supersaturated water droplets.

$[G . S$.]

DreibelBis, F. R. Some influences of frost penetration on the hydrology of small watersheds.

Transactions American Geophysical Union, Vol. 30, No. 2, 1949, p. 279-82.

An example of the influence of frost penetration on hydrologic as well as agronomic problems is presented and discussed. The data indicate that frost penetration retards percolation, thereby retaining water in the soil profile that discussed. The data indicate that frost penetration retarls per on percolation and resultant available storage may affect normally would drain. Frost penetration through its influen
infiltration for a considerable time after the frost period.

Fossa-Mancini, Enrique. Supuesto vestigios de glaciaciones del Paleozoico en la Argentina.

Revista del Museo de La Plata (Nueva Serie), Tomo I, Sección Geología, 1943, p. 347-406.

This paper discusses the criteria usually employed in interpreting certain lithological features as evidence of past glaciations, a review of the supposed traces of Palaeozoic glaciations in Argentina, and some considerations of the chronological distribution of Palaeozoic ice ages, as suggested by findings in that country.

It has been stated that in Argentina there is evidence of glaciations of Ordovician, Silurian, Early Carboniferous. Late Carboniferous, and Permian age. In most cases the evidence consists of some boulder beds with a few scratched Late Carboniferous, and Permian age. In most cases the evidence consist always these striated surfaces and the scratched

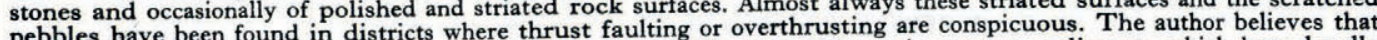
pebbles have been found in districts where thrust faulting or overthrusting are conspicuous. The aus which have locally the supposed ice pavements and many of the supposed tillites are Palaeozoic aqueous sediments which have locally acquired a peculiar appearance under the action of diastrophic forces. He therefor ice age, comparable in duration and hypothesis of multiple Palaeozoic ice ages. He believes that one Late Carbonife Palaeozoic glacial, limnoglacial, and fluviophases to that of the Pleistocene, can fully explain the distribution of all true Palaeozoic glacial, limnoglacial, and fluvio-
[From author's abstract.]

HeVERLy, J. Ross. Supercooling and crystallization. Transactions American Geophysical Unon,

Vol. 30, No. 2, 1949, p. 205-10.

The supercooling of droplets of water under conditions of cooling rate and pressure that bracket those found in nature has been quantitatively studied. Also the temperature at which water vapour in ordinary atmospheric air will nature has been quantitatively studed. Also determined. The spontantous freezing point is presented in a graph as a crystallize to form snow crystals has been determined. The spontantous freezing point is presented in a graph as a function of droplet size. Such varied wed. A photomicrograph of "formvar" (polyvinyl formal dissolved in ethylene condensed from the atmosphere werts formed is presented, and the size distribution and relative number of the accomdichloride) replicas of the snow crystais formed in tabular form, as a function of temperature. The results of the supercooling and crystallization investigations indicate that the current precipitation theories need modification. A new concept of the initiation of precipitation is presented.

[From author's abstract.]

† Yournal of Glaciology, Vol. 1, No. 3, 1948, p. 139. 